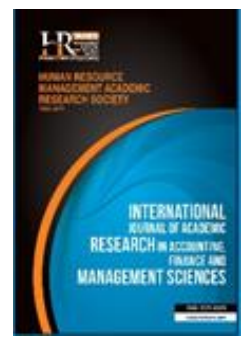

International Journal of Academic Research in Accounting, Finance and Management Sciences

Vol. 8, No.3, July 2018, pp. 336-345

E-ISSN: 2225-8329, P-ISSN: 2308-0337

(C) 2018 HRMARS

www.hrmars.com

To cite this article: Iyem, C., Ozturk, D.G., Y.ldz, F.Z. (2018). Clustering and Clustering Potential in TR 32 Regions Province, International Journal of Academic Research in Accounting, Finance and Management Sciences 8 (3): 336 345.

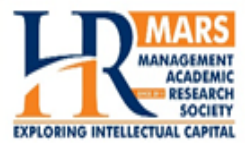

http://dx.doi.org/10.6007/IJARAFMS/v8-i3/4919 (DOI: 10.6007/IJARAFMS/v8-i3/4919)

\title{
Clustering and Clustering Potential in TR 32 Regions Province
}

\section{Cemal IYEM ${ }^{1}$, Derya Gul OZTURK ${ }^{2}$, Fatma Zehra YILDIZ ${ }^{3}$}

\author{
1,2,3 Aydin Adnan Menderes University, Aydin, Turkey, \\ 1E-mail: ciyem@adu.edu.tr, 2E-mail:derya.gul@adu.edu.tr, ${ }^{3} E$-mail: zehrayldz07@gmail.com
}

\begin{abstract}
With globalization, competition between countries, regions and industries has become more intense and complex. The concept of clustering, first expressed by Marshall in 1890 as industrial concentrations; is seen as a tool for ensuring national, regional and local competitiveness, innovation and development. Clustering, which began in the 1960s with the development of the regions where small firms with a tendency to cooperate technologically and strategically in Europe was concentrated in certain industrial regions, came up again in the 1990s with the diamond model which was included in the Porter's work called 'International Competitive Advantage'. The aim of this study is to investigate the clustering potential areas in the TR 32 region and their effects on regional competitive advantage. For this purpose, three star analysis, which is generally carried out on employment numbers, was used to define the sectors. Results of the study shows the existence of areas with clustering potential and their competitive advantage both regionally and nationally in Aydın, Denizli and Muğla provinces.

Key words Clustering, Three Star Analysis, Competitive Advantage, TR 32 Region. Clustering Potential

Received: 10 Sept 2018 (C) The Authors 2018

Revised: 18 Oct 2018 Published by Human Resource Management Academic Research Society (www.hrmars.com)

Accepted: 26 Oct 2018 This article is published under the Creative Commons Attribution (CC BY 4.0) license. Anyone may reproduce, distribute, translate and create derivative works of this article (for both commercial and noncommercial purposes), subject to full attribution to the original publication and authors. The full terms of this license may be seen at: http://creativecommons.org/licences/by/4.0/legalcode
\end{abstract}

\section{Introduction}

The concept of clustering based on competitive advantage, innovation and development is used in terms of the geographical concentration of enterprises collusively in a particular area. Porter's Diamond Model is an important basis for the concept to gain a strategic character. Clustering of sectors provides added value to products and services and at the same time provides significant cost advantage. In view of all these characteristics, the concept of clustering has taken its place in the strategic area as the subject of many researches.

The concept of clustering, which was first included in the 'Principles of Economy' written by Alfred Marshall in 1890, came up again in the 1990s with the diamond model which was included in the Porter's work called 'International Competitive Advantage'. Porter expressed that local agglomerations were effective as a source of comparative advantage of a business in the global economy. The clustering that enterprises create by focusing on specific areas as geographic or sectoral provides to reduce transaction costs and achieve competitive advantage by accessing to information, technology and qualified workforce. In addition to increasing competitiveness among enterprises, clustering is also important in terms of sectoral cooperation in the areas where enterprises are experts and development of regional economies. Besides importance of the clustering in regional development, it is seen as a structure that increases productivity and productivity in terms of enterprises and provides opportunities and competitive advantages for new product development and innovation. 
The aim of this study is to identify areas with clustering potential in the provinces of TR32. By selecting Aydın, Denizli and Muğla as sample, the clustering potentials of samples were found out. In the first chapter of the study, the historical background of the concept of clustering was examined and information about the emergence of the concept was given. Afterwards, the importance of clustering was expressed and explanations about the TR32 region which are examples of the research were presented. In the last chapter, 3-star analysis that is research method is express. In the findings section, the results of analyzes were evaluated. In the conclusion section, the conclusions reached within the framework of the purpose of the research were summarized and recommendations were made.

\subsection{The Clustering}

The concept of clustering is based on the theory of at "agglomeration economies" proposed by the famous economist Marshall ten years ago. Marshall (1920) was one of the first economists to examine the formation of British industrial zones in the $19^{\text {th }}$ century and emphasize the importance of industrial settlement and deal with the concept of cluster. Weber (1929) contributed to clustering studies by improving Marshall's work which he intends to find the most suitable place for the establishment of enterprises with the settlement theory. The growth poles that Perroux (1950) mentioned in his study of economic field theories are the clustering approach based on the understanding that the expansion of economic activities in certain regions is the basis for development. Michael Porter, who discusses Perroux's growth poles concept in terms of industrial strategies, (1999) emphasized that industrial clustering provides a basis for production, productivity growth and innovation in favor of a certain geographical location (Demirdöğen, 2013). Porter (1990) presents the idea of clustering with the diamond model in his competitiveness advantage of nations work (Erkut, 2011). In the diamond model, the question of how the nations provide competitive advantage is sought an answer (Koç ve Özbozkurt, 2014). Krugman (1999) states that the changes in spatial distribution in economic geography approach bring with the concentration of certain industries in certain regions and regional specialization. These theoretical approaches reveal that the sectoral and geographical concentration of industrial activities is extremely important in the development and industrial policies of countries or regions. However, it is possible to think the history of the cluster ahead of the industrial revolution. According to Qian (2004), the pottery and porcelain cluster in Jingdezhen, which has existed in China for more than 1400 years, has been shown as the first examples of the cluster (Sun and Perry, 2008).

According to Porter (1998), the cluster means the geographic concentration of companies and institutions connected to each other in a certain area. Geographical concentration is very important for organizational development and technological innovation (Kuah, 2002). The cluster which involves suppliers such as machinery, service includes enterprises which are interrelated and rival. The cluster has expanded to enterprises, customers in industries which are interrelated with skills, technology and common inputs. Finally, it is possible to state that many clusters include institutional and non-institutional structures such as universities, trade associations and think tanks.

Marshall (1920) is known as the first person to define "the industrial clusters". According to the famous economist, there are three reasons why firms located close to each other in a specific region are more productive and efficient than separate settlements: labour pool, supplier specialization, information distribution. In addition to all this, Marshall emphasizes that the concentration of similar firms in the same place will attract, develop and benefit better from the workforce with common characteristics. The concentration of similar firms creates a good market for suppliers and also offers a scale to improve their capabilities. Thus, increased productivity is also a benefit for customers (Cortright, 2006). According to Roelandt and den Hertog (1999), the clusters generally consist of intersectoral networks of different or complementary companies specialized around a specific link or knowledge base in the value chain.

Porter suggests "the diamond model", which consists of four variables, in determining the competitive advantage of a cluster. Accordingly, the global competitiveness of the cluster depends on the support of four variables and the creation of the diamond (Porter, 1990). This model makes significant contributions to whether or not a cluster study is to be carried out. In addition to the factor pools that consist of population, natural resources and country soil, Porter have drawn attention to factors that can be determined by nations themselves, such as qualified labor force, advanced technology and knowledge 
accumulation. The factors that constitute the diamond model of Porter are: company strategy and competition structure, input conditions, demand conditions, relevant and supportive industries (Bozkurtoğlu, 2013).

Factor conditions of a country are land, labor and capital. The education level of the labor force in the country will be effective on labor-intensive or improved service and product (Koç and Özbozkurt, 2014). Again, skilled workforce and infrastructure elements are considered as a requirement of providing competitive advantage in product factors (Porter, 1990). In addition to competitive advantage and progress, enterprises in a cluster; through the increase of productivity, knowledge sharing, innovation and specialization, enterprises can access to scale economy and increase in employment, production and exports and to provide added value to regional macroeconomics (Ceyhan and Özcan, 2018).

The characteristics of the domestic market are highly influential in how businesses perceive, understand, and respond to customer needs. The clear picture of domestic market demands on the customer needs of the companies plays a key role in ensuring the competitive advantage of the country in these industries. Customers have pushed companies to renew faster than other foreign competitors and have made it easier for them to achieve complex competitive advantages. Porter's example gives a clear perspective on this subject. Japanese customers living in small houses have received a meaningful response from producers to their complaints of rising high electricity costs with humid weather. Japanese companies have been pioneers in this field by producing energy-saving silent air conditioners (Porter, 1990).

Relevant and supportive industries constitute an important variable in ensuring competitive advantage. The fact that the supplier is close to the manufacturer is a strategic step in ensuring a competitive advantage compared to other producers of the same supplier (Koç and Özbozkurt, 2014). Strategically supplier positioning have come into prominence in the efficient, rapid and early acquisition of cost-effective inputs. Italian silver and gold jewelry companies are world leaders in this industry. In this success, metal recycling and jewelry making machines provided by other Italian companies have important contributions (Porter, 1990).

The fourth corner of the Diamond Model is strategy, structure and competition. National conditions are effective in determining how companies will be organized, managed and the nature of local competition. In Italy, for example, internationally successful competitors are small and medium-sized companies which are managed as a large family. In Germany, on the contrary, firms have a strict hierarchical structure and managers have technical infrastructure (Porter, 1990).

Rugman and D'Cruz (1993) have suggested "double diamond" model by criticizing Porter's the diamond model from various aspects. According to the study, Porter's diamond model causes serious errors when applied to economies such as Canada, which are small, open and trade intensive. If the logic of Porter's book had been strictly applied, it was highlighted that the studies describing Canada's successful cluster would be too narrow and limited.

There are several factors that need to be taken into account in the success of the clustering. These factors are classified as internal characteristics, those which are dependent on environment and policy design of clusters. In success factors related to internal characteristics, it is important to reach critical mass and prevent excessive commitment to key companies. There are factors such as social capital and strong skill base in environmental factors. Setting a long-term timeline, strengthening institutional capacity, and creating interaction among institutions constitutes the policy design factors of the clusters (Erkut, 2011). Clustering is also a network form that increases the impact and frequency of communication and interactions in a geographic region where the proximity of firms and organizations has a certain partnership (Kuah, 2002).

Today's world economic map is shaped by called the clustering structure. Silicon Valley and Hollywood in the USA, the automotive industry in the Germany, fashion design field in the Italian and the electricity and electronics sector in the Japan is known as the best examples of clustering in the world. In Turkey, clusters such as textile, ready wear, garment, food, carpets, furniture, automotive, ceramics and tourism have existed. Porter explains to be ahead in certain sectors for countries with the clustering. Clusters do not have a unique structure, but they also have their own unique qualities. There seems to be a contrast at this point: creating a competitive advantage in a global economy lies in local elements such as information, relationship and motivation (Porter, 1998). The common features of the cluster concept which 
can be defined from different perspectives in the literature are as follows: geographic proximity and concentration in the city and region, presence of social networks, presence of specialization in a field, common organization and decision-making processes, having interconnected industry branches, leading to organizational learning, development and development (Kaygalak and Karadağ, 2010).

Considering the historical cluster development in Turkey, pioneering work of the Competitive Advantage of Turkey group on increasing international competitiveness plays an important role in regional agglomeration initiatives (Erkut, 2011). Also in 2004, starting to operate in National Competitiveness Research and conducted by the Undersecretariat of Foreign Trade "Development of a Clustering Policy in Turkey" project is seen as an important step on clustering (Sarıtaş and Tunca, 2017). In 1998, the UK Ministry of Trade and Industry recognized the strategic importance of clusters and clustering, which are defined as the geographical density of competitive, cooperative and interdependent companies and organizations that are interconnected by a market and non-market links system (DTI, 1998).

Porter, in his study of local clustering in the global economy, states that the economic geography has various contradictions in the global competition environment. The changes in technology and competition reduce many of the traditional roles of a particular position. However, clustering appears to be a prominent feature of economies in developed countries. The spread of clustering provides an important perspective on the role of positioning in achieving competitive advantage In addition, the cluster strengthen local economies and concentrates a sector at a particular location; infrastructure investments for the needs of a certain sector, financial markets familiar with the sector, technology and information transfer, trained and specialized employees, the availability of special input suppliers and the availability of business services provide significant cost savings. Clustering as a result of increasing global competition and the emergence of new production technologies facilitates the transition from large firms to small firms with special production focus by industrial restructuring. Clustering encourages networking to take advantage of new markets, integrate activities, and utilize resources and information among companies. Clustering provides a better focus on public resources, targeting industrial development efforts and more efficient use of limited economic development resources of the regions. However, the cluster has some disadvantages: designing an industrial clustering program may be difficult because it requires, a comprehensive review of the region and its economic processes, determination of regional competitive advantage based on labor characteristics, original regional features, availability, public and private infrastructure quality and close proximity to input and product markets. The benefits provided to existing members of a cluster are not readily available in newer or smaller clusters that are different from those subsequently joined to the cluster in terms of competitive advantages such as cost savings, special infrastructure, enterprise support and well-developed networks. Besides, it is not easy to establish the supportive institutions needed to support the clusters due to changes in political, social and economic conditions (Barkley and Henry, 2001).

According to Izmir Development Agency of Turkey (2010) research, which is studied by the existing industries in Izmir three star clustering method used for the studies of their potential; it has been determined that sectors such as canned food sector, wedding dress and evening dress sector, chemicals sector, industrial ventilation, air-conditioning and refrigeration equipment sector, on vehicle equipment sector, road haulage and maritime transport and storage services sectors have come to the fore (IZKA, 2010). Braunerhjelm and Carlsson (1999) stated in their study on industrial clusters in the Ohio and Sweden regions, for the state of Ohio; basic metal products, rubber and plastic products, processed metal products, stone, clay and glass products; for region of Sweden, metal mining, communication, health, education and social services, paper and other products, processed metal products sectors have come to the fore.

Anderson et al. (2004) outlined the concept of clustering, strategy, vision, performance evaluation, cluster actors and objectives in the white paper they prepared about cluster policies. Obadic (2015), in their study of cluster development and mapping process, they determined that clusters in the regions located in Croatia stand out in the furniture and woodworking sector, the production of parts and accessories for motor vehicles and in the food production sectors.

As a result of Erkut (2011) 's study to reveal areas with clustering potential in Aydin province, there is a potential for clustering in Aydin province; plant and animal production sector, coal and lignite extraction sector, food production sector, electrical equipment manufacturing sector, recycling of waste material sector and accommodation sectors were determined. 
Sandal and Şen (2017) were classified as a mature cluster by taking three stars as a result of the analysis of industrial clusters with three stars analysis method in Gaziantep. These sectors are; manufacture of textile products, manufacture of leather and related products, printing and duplication of recorded media, manufacturing of rubber and plastic products, production and distribution of electric gas steam and ventilation systems.

Seki and Aslan (2018), TRC2 (Sanliurfa-Diyarbakir) region to reveal the potential of clustering in the manufacturing industry and to determine the sectors that can lead in regional development as a result of their work, manufacturing of machinery and equipment as well as motor vehicle body and trailer manufacturing sectors have been identified as sectors with high clustering potential and medium-high technology.

As it can be seen in the studies, clusters have important effects on national, regional and local economies. For example, industrial clusters include groups of firms with different characteristics, and consequently, various potentials for employment growth and local economic development (Cortright, 2006). Clusters avails in terms of lower transaction costs and concrete economic benefit creation, innovation, efficient resource utilization, knowledge generation and dissemination, better access to employees and suppliers, faster decision making, complementarity, access to institutions and public goods. For this reason, clusters should be supported in order to ensure regional and economic development.

\section{Research: Clustering and Clustering Potential in TR 32 Region Provinces}

In this section, the aim and method of the study is given and findings are evaluated.

\subsection{Purpose of the research}

The aim of this study is to define the concept of clustering which provides competitive advantage, economic benefit and welfare increase for enterprises and to identify areas with clustering potential in provinces in TR32 region. Within the scope of the study, TR 32 Region covers the provinces of the South Aegean Development Agency, Aydın (TR321), Denizli (TR322) and Muğla (TR323). The total population of Aydın province in the region in 2018 is 1,080,839, Denizli is 1,018,735 and Muğla has a population of 938,751. Approximately $35 \%$ of the population is located in Aydın, 33\% in Denizli and $30 \%$ in Muğla. In determining the region of activity is based on the classification of statistical regional units (Aydıner, 2015). For this purpose, the research question is determined as follows:

Which sectors in the TR32 region have clustering potential?

\subsection{Method of Research}

In this study, in order to determine the areas which have clustering potential in Aydın, Denizli and Muğla provinces in TR 32 region and determine their effects on regional competitive advantage, the current employment data of provinces are taken as basis. For data collection method secondary sources were preferred. Secondary data were obtained from institutions such as Turkish statistical institute, Social Security Institution (SSI), Ministry of Science, Industry and Technology and Ministry of Economy. Three star analysis was used to identify sectors with high clustering potential in the province.

The three star analysis, a quantitative method, is used to identify sectors with clustering potential based on employment data. Three Star Analysis, which is a method of numerical analysis, has been proposed within the scope of the Cluster Observatory Project to compare the cluster formation in the member states of the European Union.

This method is generally used to analyze employment data (Beyaz Kitap, 2007). The parameters of magnitude, dominance and specialization, which are the main indicators of the analysis, are given a star and sectors that receive three stars as a result of the analysis are expressed as sectors with clustering potential (Erkek ve Öselmiş, 2011). Magnitude is expressed as the ratio of employment data of a certain sector in the region to the total of the sector, in other words, the ratio to national employment.

Dominance is defined as the ratio of sector data in a region to the total data of the region. Specialization refers to the ratio of the share of a sector in the region to the share of the same sector in the country. 
In other words, it is defined as share of employment in the sector in a given region and its rate in national employment. Since there is no standard criterion in the literature, there are some common equations used for assigning stars to a sector and a threshold value is defined for these three important indicators (Beyaz Kitap, 2007; Ceyhan and Özcan, 2018).

\section{Research Findings}

In the determination of clusters, sectors with clustering potential were obtained from employment data and number of workplaces. In the study where the three star method is applied, each parameter is determined according to the following limit values for magnitude, dominance and specialization in the determination of the three star sectors.

Table 1. Three star analysis formula and threshold values

\begin{tabular}{|l|c|c|}
\hline \multicolumn{1}{|c|}{ Three Star Analysis Criteria } & Formula & Threshold value \\
\hline Magnitude & $\mathrm{e}_{\mathrm{i}} / \mathrm{E}_{\mathrm{i}}$ & $\geq 0,02$ \\
\hline Dominance & $\mathrm{e}_{\mathrm{i}} / \mathrm{e}_{\mathrm{t}}$ & $\geq 0,01$ \\
\hline Specialization & $\left(\mathrm{e}_{\mathrm{i}} / \mathrm{e}_{\mathrm{t}}\right) /\left(\mathrm{E}_{\mathrm{i}} / \mathrm{E}_{\mathrm{t}}\right)$ & 1 \\
\hline
\end{tabular}

(employment of the province in sector $\mathrm{i}$; $\mathrm{e}_{\mathrm{t}}$ : total employment of province;

$\mathrm{E}_{\mathrm{i}}$ : Turkey's employment in business sector; $\mathrm{E}_{\mathrm{t}}$ : total employment in Turkey)

Table 2. Main sectors receiving three stars in Aydın province

\begin{tabular}{|c|c|c|c|c|}
\hline Potential Sectors & Activity Groups & Magnitude & Dominance & Specialization \\
\hline $\mathbf{1}$ & Plant and animal production & 0.028 & 0,020 & 2,585 \\
\hline $\mathbf{2}$ & $\begin{array}{c}\text { Manufacture of food } \\
\text { products }\end{array}$ & 0,024 & 0,069 & 2,201 \\
\hline $\mathbf{3}$ & $\begin{array}{c}\text { Manufacture of machinery } \\
\text { and equipment }\end{array}$ & 0,024 & 0,023 & 2,208 \\
\hline $\mathbf{4}$ & Accommodation & 0,021 & 0,026 & 1,864 \\
\hline
\end{tabular}

Source: values are calculated by us using the SSI data

In the study which carried out three stars analysis for the sector, sectors that took three stars for Aydın province; sectors have been active in the fields of plant and animal production, manufacture of food products, manufacture of machinery and equipment and accommodation. Besides, fishery and aquaculture products were included in the potential cluster category with the specialization value of 3.32.

Table 3. Other indicators of sectors receiving three stars in Aydın

\begin{tabular}{|c|c|c|c|c|c|c|c|}
\hline Potential & \multirow{2}{*}{$\begin{array}{c}\text { Activity Groups } \\
\text { Sectors }\end{array}$} & \multicolumn{2}{|c|}{ Employment } & \multirow{2}{*}{ Percentage(\%) } & \multicolumn{2}{|c|}{ Firm Number } & \multirow{2}{*}{ Percentage(\%) } \\
\cline { 3 - 6 } & $\mathbf{1}$ & Aydın & Turkey & & Aydın & Turkey & \\
\hline $\mathbf{2}$ & $\begin{array}{c}\text { Plant and animal } \\
\text { production }\end{array}$ & 2992 & 104537 & 2,86 & 897 & 16356 & 5,48 \\
\hline $\mathbf{3}$ & $\begin{array}{c}\text { Manufacture of food } \\
\text { products }\end{array}$ & 10597 & 434823 & 2,43 & 856 & 41896 & 2,04 \\
\hline & $\begin{array}{c}\text { Manufacture of } \\
\text { machinery and } \\
\text { equipment }\end{array}$ & 3523 & 144100 & 2,44 & 131 & 10503 & 1,24 \\
\hline $\mathbf{4}$ & Accommodation & 3967 & 192176 & 2,06 & 409 & 17304 & 2,36 \\
\hline
\end{tabular}

As shown in Table 3, employment rate in the four sectors that emerged according to the three star method, it is $2.40 \%$ of total employment in Aydın. In addition, it has been determined that the number of firms in these sectors in Aydın is $2.66 \%$ of the total number of firms. These four sectors, which stand out in the province of Aydın, constitute $11.7 \%$ of the total number of firm and $9.79 \%$ of the total employment in the four sectors. 
Table 4. Main sectors receiving three stars in Denizli province

\begin{tabular}{|c|l|c|c|c|}
\hline Potential Sectors & \multicolumn{1}{|c|}{ Activity Groups } & Magnitude & Dominance & Specialization \\
\hline $\mathbf{1}$ & Forestry and logging & 0,031 & 0,060 & 2,311 \\
\hline $\mathbf{2}$ & Manufacture of textile products & 0,089 & 0,194 & 6,539 \\
\hline $\mathbf{3}$ & Manufacture of clothing & 0,020 & 0,049 & 1,448 \\
\hline $\mathbf{4}$ & Manufacture of non-metallic products & 0,039 & 0,045 & 2,874 \\
\hline
\end{tabular}

As a result of three stars analysis according to Table 4; forestry and logging; manufacture of textile products; manufacture of clothing and manufacture of non-metallic products. In addition, the production of paper and paper products and metal ore mining have been classified in the potential cluster category by taking stars from two of the three parameters.

Table 5. Other indicators of sectors receiving three stars in Denizli

\begin{tabular}{|c|c|c|c|c|c|c|c|}
\hline \multirow{2}{*}{$\begin{array}{l}\text { Potential } \\
\text { Sectors }\end{array}$} & \multirow{2}{*}{ Activity Groups } & \multicolumn{2}{|c|}{ Employment } & \multirow{2}{*}{ Percentage(\%) } & \multicolumn{2}{|c|}{ Firm Number } & \multirow{2}{*}{ Percentage(\%) } \\
\hline & & Denizli & Turkey & & Denizli & Turkey & \\
\hline 1 & $\begin{array}{c}\text { Forestry and } \\
\text { logging }\end{array}$ & 1088 & 34666 & 3,13 & 78 & 2994 & 2,60 \\
\hline 2 & $\begin{array}{l}\text { Manufacture of } \\
\text { textile products }\end{array}$ & 36280 & 408554 & 8,88 & 1331 & 16568 & 8,03 \\
\hline 3 & $\begin{array}{c}\text { Manufacture of } \\
\text { clothing }\end{array}$ & 9178 & 466829 & 1,96 & 307 & 32228 & 0,95 \\
\hline 4 & $\begin{array}{c}\text { Manufacture of } \\
\text { non-metallic } \\
\text { products }\end{array}$ & 8496 & 217688 & 3,90 & 333 & 13688 & 2,43 \\
\hline
\end{tabular}

As seen in Table 5, the employment rate in the four sectors, according to the three-star method, is $4,88 \%$ of the total employment in Denizli. In addition, the number of firms in these sectors in Denizli was found to be $3.12 \%$ of the total number of firms. $14,01 \%$ of the total number of firms in the four sectors with clustering potential in Denizli is $17,87 \%$ of the employment in the four sectors.

Table 6. Main sectors receiving three stars in Muğla province

\begin{tabular}{|c|l|c|c|c|}
\hline Potential Sectors & \multicolumn{1}{|c|}{ Activity Groups } & Magnitude & Dominance & Specialization \\
\hline $\mathbf{1}$ & Fishery and Aquaculture & 0,264 & 0,013 & 21,771 \\
\hline $\mathbf{2}$ & Food and beverage service & 0,020 & 0,075 & 1,690 \\
\hline $\mathbf{3}$ & Accommodation & 0,058 & 0,067 & 4,774 \\
\hline $\mathbf{4}$ & Real Estate activities & 0,032 & 0,021 & 2,634 \\
\hline
\end{tabular}

As shown in Table 6, as a result of three star analysis, the prominent sectors for Muğla are; Fishery and aquaculture, food and beverage service activities, accommodation and real estate activities. Apart from these sectors, forestry and logging, wood and wood products, mushroom production were taken into consideration in the potential cluster category by taking stars from two parameters of the analysis.

Table 7. Other indicators of sectors receiving three stars in Muğla

\begin{tabular}{|c|c|c|c|c|c|c|c|}
\hline \multirow{2}{*}{$\begin{array}{c}\text { Potential } \\
\text { Sectors }\end{array}$} & \multirow{2}{*}{ Activity Groups } & \multicolumn{2}{|c|}{ Employment } & \multirow{2}{*}{ Percentage(\%) } & \multicolumn{2}{|c|}{ Firm Number } & $\begin{array}{c}\text { Percentage } \\
\text { (\%) }\end{array}$ \\
\cline { 3 - 7 } & Denizli & Turkey & & & Denizli & Turkey & 18,15 \\
\hline $\mathbf{1}$ & $\begin{array}{c}\text { Fishery and } \\
\text { Aquaculture }\end{array}$ & 2235 & 8467 & 26,39 & 222 & 1223 & 2,85 \\
\hline $\mathbf{2}$ & $\begin{array}{c}\text { Food and } \\
\text { beverage service }\end{array}$ & 14288 & 609318 & 2,34 & 3120 & 109416 & 9,94 \\
\hline $\mathbf{3}$ & Accommodation & 11124 & 192176 & 57,7 & 1721 & 17304 & 2,63 \\
\hline $\mathbf{4}$ & $\begin{array}{c}\text { Real Estate } \\
\text { activities }\end{array}$ & 3493 & 109391 & 3,19 & 1387 & 52594 & \\
\hline
\end{tabular}


As shown in Table 7, employment rate in the four sectors that emerged according to the three star method, it is 3,38 \% of the total employment in Muğla. In addition, the number of firms in these sectors in Muğla is $3.57 \%$ of the total number of firms. $33,57 \%$ of the total number of firms in the four sectors with clustering potential in Muğla constitutes $89,62 \%$ of the total employment in the four sectors.

Table 8. TR 32 Region Provinces Foreign Trade Figures

\begin{tabular}{|l|c|c|}
\hline & Import (\$) & Export (\$) \\
\hline Aydın & 247.578 .889 & 702.007 .432 \\
\hline Denizli & 2.009 .358 .381 & 2.677 .119 .184 \\
\hline Muğla & 275.578 .796 & 448.289 .793 \\
\hline
\end{tabular}

Source: Turkish Statistical Institute, 2017

Considering the export rates in TR 32 Region provinces; Machinery and equipment, food products and beverages, quarrying and other mining sectors are placed on the top in Aydın; in terms of imports; machinery and equipment, chemicals and products and basic metal industry are placed first. In the export rate of Denizli province; textile products, basic metal industry and clothing; for import rate; basic metal industry, textile products, agriculture and livestock sectors came to the forefront. In the export rate of Muğla province; fishery, food products and beverages, mineral products, and for import rates; food products and beverages, other means of transport and machinery and equipment sectors are outstanding.

\section{Conclusions}

The cluster model studies, which have seen many examples in national and international fields, started with A. Marshall, In 1990, Porter's International Competitive Advantage work along with the study of the diamond model, it has become a subject of interest to many researchers and academicians. With its contribution to organizational performance become evident, the concept has found a wide range of application. The concept of clustering, together with the globalization process accelerated as a result of technological changes and developments, has an important place in the national and international competitive strategies and development policies for the countries. Clustering, which is the complementary of each other and which is related to each other geographically or sectorally it covers a long and challenging process in terms of applicability.

As Porter stated, operating in the same sector within the cluster model businesses, suppliers, chambers of commerce and industry, non-governmental organizations, institutions such as local and public administrations and universities are involved and only if they can work in cooperation. As Porter states, the cluster model includes enterprises, suppliers, chambers of commerce and industry, non-governmental organizations, local and public administrations, and universities, which operate in the same sector and if these organizations can work in cooperation, they can be succeed. The sectors with high clustering potential are of great importance in the determination of regional development policies and competitive strategies that are shaped according to the specific characteristics of the regions.

In this study, it is aimed to identify areas with clustering potential in the provinces located in the TR32 region. Within the framework of the aim of the study, Aydın, Muğla and Denizli provinces were chosen as examples for 87 sectors and three star analysis was used to reveal sectors with clustering potential.

As a result of the study, it was determined that the sectors that received three stars for Aydın were plant and animal production, food products production and accommodation. And it was also determined that fishery and aquaculture are also important areas. The sectors took three stars were $9,79 \%$ of the employment in Aydın. For Denizli, forestry and logging, textile products as well as the manufacture of clothing has been prominent. Besides, it is possible to say that the production of paper products is behind them. When the employment rate relations are examined, it was determined that the employment rate in the emerging sectors is $4.88 \%$ of the total employment in Denizli. When the other province selected as an example in the research is examined, the prominent sectors in Muğla are; fishery and aquaculture, food and beverage services, accommodation and real estate activities. At the same time, in terms of 
employment rate relations, it was seen that the employment rate in the four prominent sectors was 3.38\% of the total employment in Muğla.

When the results are examined, the areas with clustering potential in the provinces of Aydın, Muğla and Denizli, which are selected as examples in the study, have been identified. When these investments are made, it is thought that competitive advantage at international level can be achieved. Afterwards, it is recommended to make more comparisons by selecting more samples. Also, it was seen that it is important to conduct a competitive analysis. When required investments are made in these areas, it is thought that competitive advantage at international level can be achieved. And all, it is recommended to make more comparisons by selecting more samples and competition analysis should also be taken into account.

Investigations on the prominent sectors in these provinces and clustering initiatives will provide advantages in terms of regional development, economy and competitiveness.

\section{References}

1. Andersson, T., Schwaag-Serger, S., Sorvik, J. \& Hansson, E. W. (2004). The cluster policies whitebook. 49, pp. 371-402.

2. Arslan, M. (2018). TRC2 (Diyarbakır-Şanlıurfa) bölgesi kümelenme potansiyeli analizi. Al-Farabi Uluslararası Sosyal Bilimler Dergisi, 2 (1), pp. 32-53.

3. Aydıner, M. (2015). Teşvik sistemi kapsamındaki yatırımların ihracata ve istihdama etkisi: TR32 bölgesi üzerine bir değerlendirme. Küresel Iktisat ve Iş̧letme Çalışmaları Dergisi. 4 (8), pp. 74-87.

4. Barkley, D. L. \& Henry, M. S. (2001). Advantages and disadvantages of targeting industry clusters. Clemson, South Carolina: Clemson University Public Service Activities. pp. 1-11.

5. Bozkurtoğlu, S. (2013). Kümelenme Modeli ve Türkiye'de Kümelenme Çalışmaları İzmir: İzmir Ticaret Odası.

6. Braunerhjelm, P. \& Carlsson, B. (1999). Industry Clusters in Ohio and Sweden, 1975-1995. Small Business Economics, 12 (4), pp. 279-293.

7. Ceyhan, M.S. ve Özcan, S. Ö. (2018). Bölgesel kalkınmada kümelenmenin rolü: Bartın ili ayakkabıcılık sektörü örneği. AiBÜ Sosyal Bilimler Enstitüsü Dergisi. 18 (1). 141-163.

8. Cortright, J. (2006). Making Sense of Cluters: Regional Competitiveness and Economic Devolopment. The Brookings Institution.

9. DTM. (2008). Beyaz Kitap: Türkiye'de kümelenme politikasının geliştirilmesi. Ankara: Dış Ticaret Müşteşarlığı.

10.Erkek, D. ve Öselmiş, G. (2011). TR32 Düzey 2 Bölgesi'nde kümelenme yaklaşımı. GEKA.

11.Demirdöğen, S. (2013). İşletmeler için kümelenmenin önemi ve kümelenme için uygun sektörün belirlenmesi: Erzincan ili üzerine bir uygulama. Atatürk Üniversitesi Sosyal bilimler enstitüsü işletme anabilim dalı, Yayımlanmamış yüksek lisans tezi. Erzurum.

12.Erkut, F. Ç. (2011). Kümelenme ve Aydın ilindeki kümelenme potansiyeli olan alanlar. Adnan Menderes Üniversitesi Sosyal bilimler enstitüsü işletme anabilim dalı, Yayımlanmamış yüksek lisans tezi. Aydın.

13.ízmir Kalkınma Ajansı (2010). İzmir kümelenme analizi. (iZKA, Erişim, 20.06.2018).

14.Kaygalak, i. ve Karadağ, A. (2010). Türkiye'de sanayi kümelerini tanımlama ve belirleme sorunu. Üniversite sanayi işbirliği Ulusal Kongresi, ODTÜ Ankara.

15.Koç, M. ve Özbozkurt, O. B. (2014). Ulusların rekabet üstünlüğü ve Elmas modeli üzerine bir değerlendirme. İşletme ve iktisat Çalışmaları Dergisi. 2 (3), pp. 85-91.

16.Krugman, P.(1999). The Role of Geography in Development. International Regional Science Review, 22 (2), pp. 142-161.

17.Kuah, A. T. (2002). Cluster theory and practice: Advantages for the small business locating in a vibrant cluster. Journal of Research in Marketing and Entrepreneurship, 4 (3), pp. 206-228.

18.Obadic, A. (2015). Cluster development and mapping process in Croatia. Economic and Social Development: Book of Proceedings, 529.

19.Perroux, F. (1950). Economic Space: Theory and Applications. Oxford Journals, The Quarterly Journal of Economics, 64 (1), pp. 89-104. 
20.Porter, M. E. (1990). The Competitive Advantage of Nations. Harvard Business Review.

21.Porter, M. (1998). Clusters and New Economics of Competition. Harvard Business Review.

22.Porter, (2000). "Location, Competition, and Economic Development: Local Clusters in a Global Economy". Economic Development Quarterly, 14 (1), pp. 15-34.

23. Roelandt, T. \& P. den Hertog (1999). Cluster analysis and cluster-based policy making in OECDcountries, forthcoming at the OECD in 1999.

24.Sarıtaş, A. ve Tunca, M. Z. (2017). Porter modeline dayalı sektörel kümeleme analizi: Batı Akdeniz bölgesinde bir uygulama. Mehmet Akif Ersoy Üniversitesi Sosyal Bilimler Enstitüsü Dergisi. 9 (18), pp. 82-97.

25.Sun, Z. ve Perry, M. (2008). The role of trading cities in the development of Chinese business cluster. International Business Research. 1 (2), pp. 69-81.

26.Şen, Ö. Ve Sandal E. K. (2017). Gaziantep ilinde üç yıldız analizi yöntemi ile endüstriyel kümelenme analizi. Doğu Coğrafya Dergisi, 22 (38), pp. 39-62.

27.Weber, A. (1929). Theory of the Location of Industries. Chicago, IL: University of Chicago Press. 